\title{
Wpływ perlitu pylistego na własności technologiczne zaczynu cementowego
}

\begin{abstract}
W artykule przedstawiono wpływ domieszki perlitu pylistego na parametry zarówno świeżego, jak również stwardniałego zaczynu cementowego. Obecność perlitu w technologiach budowlanych znana jest już od dłuższego czasu, jednak w przemyśle naftowym nie był on wykorzystywany. Dlatego też postanowiono poddać badaniom zaczyny cementowe z domieszką najdrobniejszych frakcji perlitu, który określa się mianem perlitu pylistego bądź perlitu filtracyjnego. Środka tego użyto w celu regulacji parametrów technologicznych świeżego zaczynu cementowego oraz poprawy mikrostruktury płaszcza cementowego. Drobne frakcje dodatków i domieszek umożliwiają z reguły wypełnienie przestrzeni międzyziarnowych, dzięki czemu możliwe jest uzyskanie szczelnej matrycy płaszcza cementowego. Wspomnieć należy, iż dodatkowa cecha perlitu, którą jest jego bardzo niski ciężar właściwy, umożliwia zaprojektowanie zaczynu cementowego o obniżonej gęstości. Jest to korzystne na przykład podczas uszczelniania horyzontów wykazujących prawdopodobieństwo ucieczek podczas prac rekonstrukcyjnych lub posiadających niskie gradienty szczelinowania. Jednak w tym celu stosowane są znacznie większe ilości tego środka. W trakcie realizacji prac badawczych, których celem było określenie wpływu domieszki perlitu na parametry technologiczne zaczynu cementowego, zastosowano perlit pylisty $0,5 \% \mathrm{w}$ stosunku do ilości masy cementu. W celu wychwycenia zmian w parametrach zaczynów sporządzono receptury kontrolne. Określone zostały takie właściwości zaczynu jak: parametry reologiczne, filtracja, czas gęstnienia, odstój wody, stabilność sedymentacyjna. Dla próbek stwardniałych zaczynów określono wpływ domieszki na parametry mechaniczne (wytrzymałość na ściskanie) i parametry fizykomechaniczne (przyczepność do rur stalowych i przyczepność do formacji skalnej). Dodatkowo stwardniały zaczyn cementowy poddano badaniom opisującym mikrostrukturę próbki i wykonano badania porowatości oraz przepuszczalności. W celu określenia wpływu domieszki perlitu pylistego na parametry zaczynu i powstałego z niego stwardniałego zaczynu, badania przeprowadzone zostały dla receptur przeznaczonych do uszczelniania otworów w warunkach otworowych o temperaturze od $30^{\circ} \mathrm{C}$ do $90^{\circ} \mathrm{C}$ oraz ciśnieniu od $5 \mathrm{MPa}$ do $35 \mathrm{MPa}$.
\end{abstract}

Słowa kluczowe: zaczyn cementowy, perlit ekspandowany, własności technologiczne zaczynu cementowego, szczelność płaszcza cementowego, drobne frakcje, stabilność sedymentacyjna.

\section{Effect of perlite admixture on technological properties of cement slurry}

The article presents the effect of perlite admixture on the parameters of fresh and set cement slurry. The presence of perlite in construction technologies has been known for a long time, however, in the oil industry, perlite has not been used. Therefore, it was decided to undertake research on cement slurries with the admixture of the finest fractions of perlite, which are called perlite dust or filter perlite. This agent was used to adjust the technological parameters of fresh cement slurry and enhance the microstructure of cement sheath. Fine fractions of filler additives and admixtures usually fill the intergranular space, which makes it possible to obtain a sealed matrix of the cement sheath. It should be mentioned that an additional feature of perlite, which is its very low specific gravity, is that it allows the design of a low density cement slurry. This is an advantage when, for example: sealing the horizons with probability of leakage during reconstruction work or low pressure gradient. However, much larger amounts of this agent are used for this purpose. During research, which were aimed at investigating the effect of perlite admixture on the technological parameters of the cement slurry, perlite dust was used in a specified ( $0.5 \%)$ amount to weight of cement. In order to detect the changes in the parameters of slurries, base cement slurry was prepared. The properties of the cement slurry such as: rheological parameters, fluid loss, thickening time, free water and sedimentation stability were determined. For samples of hardened cement slurry, the effect of the admixture on mechanical parameters (compressive strength), physico-mechanical parameters (adhesion to steel pipes and adhesion to rock formation) were determined. In addition, the set cement slurry was subjected to microstructure analysis and porosity and permeability tests were also performed. In order to determine the effect of dust perlite on the parameters of fresh and hardened cement slurry, tests were conducted for cement slurries designed to seal wells under hole conditions of $30^{\circ} \mathrm{C}$ to $90^{\circ} \mathrm{C}$ and pressure from $5 \mathrm{MPa}$ to $35 \mathrm{MPa}$. 
Key words: cement slurry, expanded perlite, technological properties of cement slurry, tightness of cement sheath, fine fractions, sedimentation stability.

\section{Wprowadzenie}

Rozwój technologii uszczelniania kolumn rur okładzinowych w otworach wiertniczych powoduje konieczność ciągłego poszukiwania nowych środków umożliwiających poprawę parametrów technologicznych projektowanych zaczynów cementowych. Podczas opracowywania innowacyjnych receptur zaczynów badaniom poddawane są różnego rodzaju dodatki i domieszki, które pozwalają na otrzymanie receptury o wymaganych parametrach technologicznych. Odpowiedni dobór środka modyfikującego parametry technologiczne zaczynu powinien skutkować otrzymaniem składu, który będzie wykazywał [8, 10, 16, 17, 20]:

- odpowiednią kompatybilność z uszczelnianą formacją skalną o zróżnicowanym wykształceniu litologicznym,

- minimalny przyrost objętości w trakcie hydratacji zaczynu, co pozwoli ograniczyć ewentualność „odklejania” się płaszcza cementowego od formacji skalnej i kolumny rur okładzinowych,

- odpowiednią odporność na niszczące działanie silnie zmineralizowanych wód złożowych,

- właściwą stabilność sedymentacyjną, niską wartość odstoju oraz filtracji,

- odpowiednie parametry decydujące o efektywności uszczelnienia (czas gęstnienia dostosowany do warunków otworowych).

Niejednokrotnie podczas opracowywania zaczynów cementowych w przemyśle wiertniczym badaniom poddawane są dodatki i domieszki stosowane w branży budowlanej. Jednak wymagania dla zaczynów wykorzystywanych w przemyśle wiertniczym są znacznie bardziej restrykcyjnie z uwagi na panujące ciśnienia, temperatury oraz cały proces uszczel- niania otworu wiertniczego. W związku z powyższym zastosowane $\mathrm{w}$ opracowywanej recepturze środki poprawiające parametry technologiczne zaczynu cementowego poddawane są badaniom laboratoryjnym przy użyciu specjalistycznej aparatury $[1,3,4,12]$. Uzyskanie korzystnych parametrów technologicznych skutkuje prowadzeniem dalszych prac weryfikacyjnych, których wyniki pozwalają określić możliwość ewentualnego zastosowania danego środka dla konkretnych warunków geologiczno-technicznych.

W ostatnich latach obserwuje się zwiększoną ilość wierceń otworów horyzontalnych i kierunkowych, stąd też placówki badawcze skupiają się na projektowaniu receptur zaczynów przeznaczonych do uszczelniania tego rodzaju otworów. Głównym wymaganiem dla tego typu otworów jest uzyskanie homogenicznej struktury zarówno płynnego, jak i stwardniałego zaczynu cementowego, który nie będzie ulegał sedymentacji $[2,5]$. Warunek ten musi być ściśle przestrzegany, ponieważ zjawisko „segregowania” składników zaczynu cementowego jest znacznie bardziej widoczne w otworach kierunkowych niż w otworach pionowych. W celu poprawy stabilności sedymentacyjnej zaczynu cementowego oraz uzyskania homogenicznej struktury płaszcza cementowego stosuje się środki umożliwiające utrzymanie fazy stałej w całej objętości zaczynu zatłoczonego w uszczelnianą przestrzeń pierścieniową. Możliwe jest to dzięki zastosowaniu dodatków i domieszek drobnoziarnistych $[14,18]$. W ostatnich latach spore zainteresowanie zyskuje perlit. W związku z tym w niniejszej publikacji przedstawiono wyniki badań nad wpływem domieszki perlitu pylistego na własności technologiczne zaczynu cementowego oraz na poprawę stabilności sedymentacyjnej.

\section{Drobnoziarniste pucolanowe dodatki i domieszki do zaczynów - perlit pylisty}

Dodatki i domieszki pucolanowe to materiały naturalne lub sztuczne zawierające krzemionkę w postaci reaktywnej. Bardziej formalna definicja według normy ASTM 6118 94a [14] określa pucolanę jako materiał krzemionkowy lub krzemionkowo-glinowy, który posiada niewielkie właściwości wiążące lub nie wykazuje ich wcale. Materiał ten w postaci drobnoziarnistej przy obecności wilgoci reaguje chemicznie z wodorotlenkiem wapnia w temperaturze normalnej, tworząc związki o właściwościach wiążących $[6,11,19]$. Forma drobnoziarnista jest istotna z punktu widzenia zdolności reagowania dodatków i domieszek pucolanowych z $\mathrm{Ca}(\mathrm{OH})_{2}$. Wodorotlenek wapnia powstały wskutek hydratacji cementu tworzy w obecności wody hydrokrzemiany wapnia, które mają właściwości wiążące. Materiały pucolanowe mogą być pochodzenia sztucznego/przemysłowego (najczęściej pod postacią popiołów lotnych oraz mikrokrzemionki) lub naturalnego, jak omawiany w niniejszej publikacji perlit pylisty bądź popioły wulkaniczne, łupki opałowe czy rogowce $[9,12]$.

Perlit to materiał, który stanowi przeobrażoną skałę magmową zbudowaną ze szkliwa wulkanicznego. Jest to głównie uwodniony kwaśny glinokrzemian potasowo-sodowy zawierający również inne pierwiastki. Jego główny skład to krzemionka oraz tlenki glinu, sodu, potasu, magnezu, wapnia i żelaza. Zawartości poszczególnych składników przedstawia rysunek 1. 


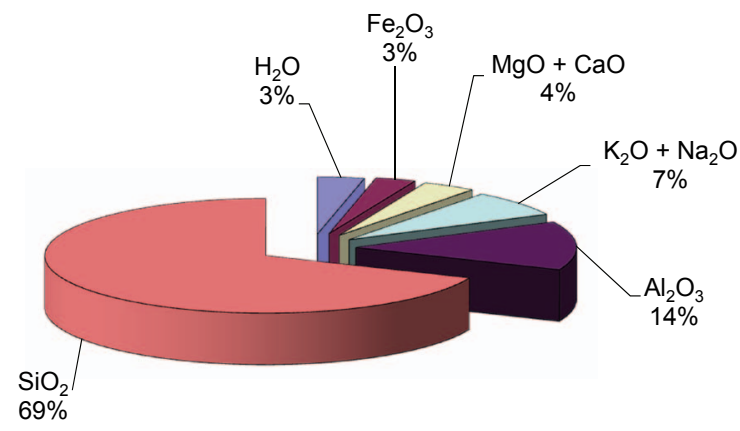

Rys. 1. Udział procentowy składników perlitu

Gęstość perlitu naturalnego (w formie skalnej) wynosi od $2230 \mathrm{~kg} / \mathrm{m}^{3}$ do $2400 \mathrm{~kg} / \mathrm{m}^{3}$ [7, 15]. Jednak do celów przemysłowych najczęściej stosowany jest perlit poddany procesowi ekspandyzacji (spęczniania). Polega on na wyprażaniu wydobytej rudy perlitu $\mathrm{w}$ temperaturze od $950^{\circ} \mathrm{C}$ do $1150^{\circ} \mathrm{C}$, w wyniku czego zamknięta w pustych przestrzeniach woda gwałtownie paruje, a skutkiem wzrostu prężności pary wodnej jest rozkruszenie mikrostruktury na drobne cząsteczki rzędu mikrometrów. W wyniku tego procesu objętości ziaren zwiększają się nawet 20-krotnie (w zależności od ilości wody zawartej w rudzie), a gęstość perlitu może wynosić około $30 \mathrm{~kg} / \mathrm{m}^{3}$ [15]. Takie właściwości danego środka czynią z niego bardzo dobry wypełniacz zmniejszający gęstości zaczynu cementowego, który dodatkowo wykazuje właściwości pucolanowe. Stosowanie perlitu w celu obniże- nia gęstości zaczynu cementowego pozwala przeciwdziałać ewentualnym ucieczkom cementu w słabych strefach. Istnieje również (w szczególnych przypadkach) możliwość wykonania mniejszej ilości stopni cementowań $[13,14]$.

Perlit z uwagi na znacznie rozwiniętą powierzchnię właściwą wykazuje właściwości wodożądne. Należy mieć powyższe na uwadze i podczas projektowania zaczynu cementowego zawierającego perlit zastosować środek upłynniający w celu uzyskania wymaganych parametrów reologicznych. Istnieje również możliwość posiłkowania się większą ilością wody w zaczynie, co jednak może skutkować frakcjonowaniem zaczynu oraz zmianą jego pozostałych parametrów technologicznych.

$\mathrm{Na}$ podstawie danych literaturowych [19] stwierdzono, że stosowanie perlitu w zaprawach budowlanych może przyczynić się do poprawy płynności i przyczepności produktu finalnego. Wzrasta również odporność na podciąganie kapilarne, co jest korzystne z punktu widzenia zaczynów cementowych przeznaczonych do uszczelniania kolumn rur okładzinowych mających kontakt z wodami siarczanowymi oraz wykazującymi działanie korozyjne. Należy wspomnieć, że literatura nie podaje wyników badań zaczynów cementowych $\mathrm{z}$ domieszką perlitu stosowanych w przemyśle naftowym. W związku z powyższym przeprowadzona została analiza wpływu domieszki perlitu pylistego na parametry technologiczne zaczynów cementowych, a wyniki zrealizowanych prac przedstawiono w niniejszym artykule.

\section{Przebieg prac badawczych}

Badania mające na celu określenie wpływu domieszki perlitu pylistego na własności technologiczne zaczynu cementowego zostały wykonywane w Laboratorium Zaczynów Uszczelniających INiG - PIB w oparciu o normy: PN-85/ G-02320 Cementy $i$ zaczyny cementowe do cementowania w otworach wiertniczych; PN-EN 10426-2 Przemyst naftowy i gazowniczy. Cementy i materiały do cementowania otworów. Część 2: Badania cementów wiertniczych oraz API SPEC 10 Specification for materials and testing for well cements.

Zaprezentowany w niniejszej publikacji cykl badawczy polegał na wykazaniu wpływu domieszki drobnych frakcji perlitu na własności technologiczne zaczynu cementowego.

Aby określić wpływ perlitu pylistego na własności technologiczne zaczynu cementowego oraz powstałego z niego płaszcza cementowego w otworze wiertniczym poddano badaniom osiem zaczynów cementowych. Sporządzone zostały cztery receptury kontrolne w celu ustanowienia punktu odniesienia. Zaczynami modyfikowanymi były cztery składy z domieszką perlitu pylistego w ilości stałej dla wszystkich zaczynów. Aby wychwycić działania drobnych frakcji perlitu na własności technologiczne zaczynu w możliwie sze- rokim spektrum warunków otworowych badania wykonano odpowiednio dla temperatur: $30^{\circ} \mathrm{C}, 50^{\circ} \mathrm{C}, 70^{\circ} \mathrm{C}$ i $90^{\circ} \mathrm{C}$, oraz odpowiadających im ciśnień: $5 \mathrm{MPa}, 18 \mathrm{MPa}, 25 \mathrm{MPa}$ i $35 \mathrm{MPa}$. Do badań wykorzystano perlit pylisty określany również mianem perlitu filtracyjnego. Podczas projektowania zaczynów cementowych materiałem wiążącym był cement wiertniczy G HSR. Głównym warunkiem takiego wyboru było stosowanie tego rodzaju cementu w warunkach przemysłowych. Podczas uszczelniania kolumn rur okładzinowych w płytkich otworach niejednokrotnie używany jest również cement portlandzki klasy CEM I 32,5R. Jednak podczas realizacji cyklu badawczego we wszystkich recepturach zastosowano cement G HSR w celu wyeliminowania możliwości powstawania błędów pomiaru wynikających ze stosowania różnych rodzajów spoiw. W celu doszczelnienia matrycy płaszcza cementowego we wszystkich recepturach wykorzystano 20-procentową ilość dodatku mikrocementu. Przyjęto stały współczynnik wodno-cementowy równy 0,50 ; jedynie receptura dla warunków otworowych o temperaturze $70^{\circ} \mathrm{C}$ i ciśnieniu $25 \mathrm{MPa}$ charakteryzowała się ilością wody o w/c $=0,57$. Składniki takie jak środek antyfiltracyjny 
Tablica 1. Receptury zaczynów cementowych dla warunków otworowych

Spoiwo wiążące: cement G HSR $=100 \%$, mikrocement $20,0 \%$

\begin{tabular}{|c|c|c|c|c|c|c|c|c|c|c|c|c|}
\hline Lp. & $\begin{array}{c}\text { Skład (nr) } \\
\text { współczynnik } \\
(\mathrm{w} / \mathrm{c})\end{array}$ & $\begin{array}{c}\text { Temperatura } \\
{\left[{ }^{\circ} \mathrm{C}\right]} \\
\text { Ciśnienie } \\
{[\mathrm{MPa}]}\end{array}$ & 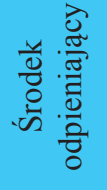 & 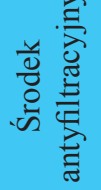 & 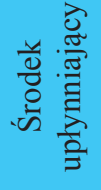 & 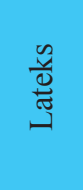 & 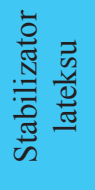 & 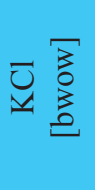 & 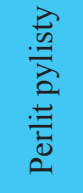 & 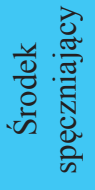 & $\tilde{J}^{\pi}$ & 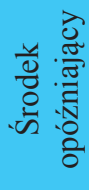 \\
\hline 1. & $\begin{array}{c}\mathrm{Nr} 1 \\
\mathrm{w} / \mathrm{c}=0,50\end{array}$ & \multirow{2}{*}{$\begin{array}{c}30^{\circ} \mathrm{C} \\
5 \mathrm{MPa}\end{array}$} & 0,3 & 0,20 & 0,20 & 10,0 & 1,0 & 3,0 & - & 0,3 & 4,0 & - \\
\hline 2. & $\begin{array}{c}\mathrm{Nr} 2 \\
\mathrm{w} / \mathrm{c}=0,50\end{array}$ & & 0,3 & 0,20 & 0,20 & 10,0 & 1,0 & 3,0 & 0,50 & 0,3 & 2,0 & - \\
\hline 3. & $\begin{array}{c}\mathrm{Nr} 3 \\
\mathrm{w} / \mathrm{c}=0,50\end{array}$ & \multirow{2}{*}{$\begin{array}{c}50^{\circ} \mathrm{C} \\
18 \mathrm{MPa}\end{array}$} & 0,3 & 0,20 & 0,10 & 10,0 & 1,0 & 3,0 & - & 0,3 & - & 0,10 \\
\hline 4. & $\begin{array}{c}\mathrm{Nr} 4 \\
\mathrm{w} / \mathrm{c}=0,50\end{array}$ & & 0,3 & 0,20 & 0,10 & 10,0 & 1,0 & 3,0 & 0,50 & 0,3 & - & 0,10 \\
\hline 5. & $\begin{array}{c}\mathrm{Nr} 5 \\
\mathrm{w} / \mathrm{c}=0,57\end{array}$ & \multirow{2}{*}{$\begin{array}{c}70^{\circ} \mathrm{C} \\
25 \mathrm{MPa}\end{array}$} & 0,4 & 0,20 & 0,20 & 10,0 & 1,0 & 3,0 & - & 0,3 & - & 0,05 \\
\hline 6. & $\begin{array}{c}\mathrm{Nr} 6 \\
\mathrm{w} / \mathrm{c}=0,57\end{array}$ & & 0,4 & 0,20 & 0,20 & 10,0 & 1,0 & 3,0 & 0,50 & 0,3 & - & 0,05 \\
\hline 7. & $\begin{array}{c}\mathrm{Nr} 7 \\
\mathrm{w} / \mathrm{c}=0,50\end{array}$ & \multirow{2}{*}{$\begin{array}{c}90^{\circ} \mathrm{C} \\
35 \mathrm{MPa}\end{array}$} & 0,5 & 0,20 & 0,25 & 10,0 & 1,0 & 3,0 & - & 0,3 & - & 0,25 \\
\hline 8. & $\begin{array}{c}\mathrm{Nr} 8 \\
\mathrm{w} / \mathrm{c}=0,50\end{array}$ & & 0,5 & 0,20 & 0,25 & 10,0 & 1,0 & 3,0 & 0,50 & 0,3 & - & 0,25 \\
\hline
\end{tabular}

i spęczniający zastosowano w stałych ilościach wynoszących odpowiednio: $0,2 \%$ bwoc oraz $0,3 \%$ bwoc (tablica 1 ). Użyto również stałych ilości lateksu $\left(10 \%\right.$ bwoc $\left.^{1}\right)$ oraz stabilizatora lateksu ( $1 \%$ bwoc). Zaczyny sporządzono na bazie wody zarobowej o 3-procentowym zasoleniu (bwow ${ }^{2}$ ). Środek odpieniający, upłynniający, przyspieszający i opóźniający czas wiązania zastosowano w ilościach podanych w tablicy 1 . Domieszki perlitu pylistego użyto w stałej dla wszystkich receptur ilości 0,5\% (bwow). Odmierzoną ilość perlitu pylistego zmieszano z cementem i dawkowano w ostatnim etapie sporządzania zaczynu (po wcześniejszym ujednorodnieniu wszystkich środków w wodzie zarobowej).

Dla określonych warunków otworopodobnych odpowiadających danej temperaturze i ciśnieniu sporządzono cztery receptury kontrolne oraz opracowano cztery zaczyny zmodyfikowane, na podstawie których możliwe było określenie wpływu domieszki perlitu pylistego na własności technologiczne zaczynów w danych warunkach. Dokładne ilości poszczególnych składników zestawiono w tablicy 1 .

Na podstawie analizy uzyskanych wyników badań stwierdzono obniżenie gęstości zaczynów po zastosowaniu domieszki perlitu w porównaniu z zaczynami bazowymi (rysunek 2, tablica 2). Jest to logiczne z uwagi na stosowanie

${ }^{1} \mathrm{Bwoc}-\mathrm{w}$ stosunku do masy cementu (ang. by weight of cement). ${ }^{2}$ Bwow - w stosunku do masy wody (ang. by weight of water). lekkich frakcji w celu regulacji gęstości zaczynu, przy czym zauważyć należy, że tak niewielka koncentracja domieszki perlitu $(0,5 \%$ bwoc) powoduje obniżenie gęstości w przedziale od wartości minimalnej równiej $20 \mathrm{~kg} / \mathrm{m}^{3}$ - w przypadku zaczynu nr 8, do wartości maksymalnej wynoszącej $85 \mathrm{~kg} / \mathrm{m}^{3}$ - dla receptury oznaczonej numerem 2 . Tak znaczne różnice mogą być spowodowane obecnością pozostałych dodatków i domieszek modyfikujących parametry zaczynu. Najmocniejsze obniżenie gęstości $\left(85 \mathrm{~kg} / \mathrm{m}^{3}\right.$ w zaczynie $\mathrm{nr} 2$ w porównaniu z zaczynem nr 1) może być tłumaczone obecnością w zaczynie chlorku wapnia, który posiada właściwości higroskopijne oraz powoduje wzrost lepkości zaczynu. Pewna objętość wody w zaczynie zawierającym $\mathrm{CaCl}_{2}$ zostaje zaadsorbowana przez chlorek wapnia, wskutek czego mniejsza ilość wody wypełnia mocno rozwiniętą powierzchnię cząsteczek perlitu. Przekłada się to na mocniejsze obniżenie gęstości zaczynu zawierającego w składzie chlorek wapnia.

Stosowanie domieszki perlitu pylistego spowodowało poprawę stabilności sedymentacyjnej zaczynów z domieszką perlitu w porównaniu z zaczynami niezwierającymi tej domieszki. W tablicy 2 oraz na rysunku 3 zestawiono wartości gęstości w poszczególnych punktach pomiarowych podczas badania w kolumnie sedymentacyjnej (fotografia 1). Sporządzony w celu zobrazowania poprawy stabilności sedymentacyjnej rysunek 4 przedstawia różnicę gęstości zaczynu w poszczególnych punktach pomiarowych. Zaczyny bazowe wykazują różnicę w gęstości pomiędzy górnym a środkowym oraz środkowym 


\begin{tabular}{|c|c|c|c|c|c|c|c|c|c|c|c|c|c|c|c|c|c|}
\hline \multirow{2}{*}{ 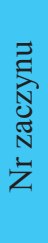 } & \multirow{2}{*}{ 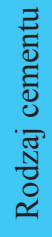 } & \multirow{2}{*}{$\begin{array}{c}\text { Temperatura } \\
{\left[{ }^{\circ} \mathrm{C}\right]} \\
\text { Ciśnienie } \\
{[\mathrm{MPa}]}\end{array}$} & \multirow[t]{2}{*}{ 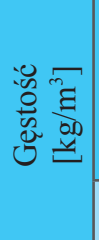 } & \multicolumn{3}{|c|}{$\begin{array}{l}\text { Stabilność sedymenta- } \\
\text { cyjna (gęstość w punk- } \\
\text { cie pomiaru) } \\
{\left[\mathrm{kg} / \mathrm{m}^{3}\right]}\end{array}$} & \multirow{2}{*}{ 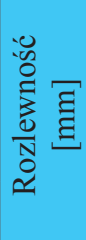 } & \multirow{2}{*}{$\begin{array}{l}\frac{3}{8} \\
\vdots \\
3 \\
\frac{0}{0} \\
\frac{0}{0} \\
0\end{array}$} & \multirow{2}{*}{ 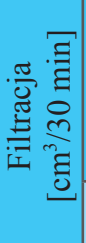 } & \multicolumn{2}{|c|}{$\begin{array}{l}\text { Czas gęstnienia* } \\
\text { [godz.:min] }\end{array}$} & \multicolumn{6}{|c|}{$\begin{array}{l}\text { Odczyty z aparatu Fann } \\
\text { [j.f.* }{ }^{* *} \text { pry obr./min] }\end{array}$} \\
\hline & & & & góra & środek & dół & & & & $30 \mathrm{Bc}$ & $100 \mathrm{Bc}$ & 600 & 300 & 200 & 100 & 6 & 3 \\
\hline 1. & \multirow{8}{*}{$\begin{array}{l}\mathscr{\alpha} \\
\mathbb{N} \\
0\end{array}$} & \multirow{2}{*}{$\begin{array}{l}30^{\circ} \mathrm{C} \\
5 \mathrm{MPa}\end{array}$} & 1885 & 1880 & 1885 & 1890 & 245 & 0,2 & 46 & $4: 20$ & $4: 50$ & 190 & 107 & 78 & 45 & 14 & 10 \\
\hline 2. & & & 1800 & 1800 & 1800 & 1800 & 235 & 0,4 & 27 & 4:04 & $4: 34$ & 203 & 114 & 83 & 51 & 16 & 15 \\
\hline 3. & & \multirow{2}{*}{$\begin{array}{l}50^{\circ} \mathrm{C} \\
18 \mathrm{~Pa}\end{array}$} & 1840 & 1830 & 1840 & 1850 & 215 & 0,2 & 56 & $3: 17$ & $3: 39$ & 207 & 119 & 89 & 55 & 16 & 14 \\
\hline 4. & & & 1810 & 1810 & 1810 & 1810 & 205 & 0,6 & 171 & 3:04 & $3: 30$ & 235 & 137 & 101 & 63 & 18 & 16 \\
\hline 5. & & \multirow{2}{*}{$\begin{array}{l}70^{\circ} \mathrm{C} \\
25 \mathrm{~Pa}\end{array}$} & 1780 & 1765 & 1780 & 1795 & 290 & 0,3 & 70 & $4: 10$ & $4: 50$ & 131 & 70 & 49 & 27 & 3 & 2 \\
\hline 6. & & & 1750 & 1750 & 1750 & 1750 & 280 & 0,9 & 180 & $3: 35$ & 4:09 & 139 & 74 & 52 & 29 & 3 & 2 \\
\hline 7. & & \multirow{2}{*}{$\begin{array}{l}90^{\circ} \mathrm{C} \\
35 \mathrm{~Pa}\end{array}$} & 1840 & 1835 & 1840 & 1845 & 265 & 0,0 & 82 & $6: 02$ & $6: 52$ & 216 & 120 & 85 & 49 & 6 & 4 \\
\hline 8. & & & 1820 & 1820 & 1820 & 1820 & 255 & 0,0 & 202 & 5:04 & $5: 50$ & 235 & 130 & 92 & 53 & 7 & 4 \\
\hline
\end{tabular}

Objaśnienie

${ }^{*}$ Czas dojścia do temperatury:

$30^{\circ} \mathrm{C}=10 \mathrm{~min} \quad 70^{\circ} \mathrm{C}=40 \mathrm{~min}$

$50^{\circ} \mathrm{C}=25 \mathrm{~min} \quad 90^{\circ} \mathrm{C}=60 \mathrm{~min}$

${ }^{* *}$ j.f. - jednostki Fann

Tablica 3. Parametry reologiczne zaczynów cementowych

\begin{tabular}{|c|c|c|c|c|c|c|c|c|c|}
\hline \multirow{2}{*}{$\begin{array}{l}\text { Model } \\
\text { reologiczny }\end{array}$} & \multirow{2}{*}{ Parametry reologiczne } & \multicolumn{8}{|c|}{ Zaczyn nr: } \\
\hline & & 1 & 2 & 3 & 4 & 5 & 6 & 7 & 8 \\
\hline \multirow{2}{*}{$\begin{array}{c}\text { Model } \\
\text { Newtona }\end{array}$} & Lepkość dynamiczna $[\mathrm{Pa} \cdot \mathrm{s}]$ & 0,0998 & 0,1067 & 0,1100 & 0,1252 & 0,0673 & 0,0713 & 0,1125 & 0,1222 \\
\hline & Współczynnik korelacji [-] & 0,9861 & 0,9816 & 0,9775 & 0,9767 & 0,9974 & 0,9973 & 0,9939 & 0,9942 \\
\hline \multirow{3}{*}{$\begin{array}{c}\text { Model } \\
\text { Binghama }\end{array}$} & Lepkość plastyczna $[\mathrm{Pa} \cdot \mathrm{s}]$ & 0,0899 & 0,0944 & 0,0966 & 0,1099 & 0,0647 & 0,0686 & 0,1063 & 0,1155 \\
\hline & Granica płynięcia [Pa] & 6,9568 & 8,6391 & 9,4213 & 10,8400 & 1,8117 & 1,9045 & 4,4093 & 4,7111 \\
\hline & Współczynnik korelacji [-] & 0,9985 & 0,9991 & 0,9973 & 0,9970 & 0,9990 & 0,9989 & 0,9975 & 0,9977 \\
\hline \multirow{3}{*}{$\begin{array}{c}\text { Model } \\
\text { Ostwalda } \\
\text { de Waele'a }\end{array}$} & Współczynnik konsystencji $\left[\mathrm{Pa} \cdot \mathrm{s}^{\mathrm{n}}\right]$ & 2,0184 & 2,9319 & 2,7547 & 3,1215 & 0,2593 & 0,2537 & 0,5591 & 0,5961 \\
\hline & Wykładnik potęgowy [-] & 0,5263 & 0,4770 & 0,4952 & 0,4963 & 0,7894 & 0,8028 & 0,7524 & 0,7557 \\
\hline & Współczynnik korelacji [-] & 0,9618 & 0,9493 & 0,9643 & 0,9659 & 0,9990 & 0,9063 & 0,9963 & 0,9964 \\
\hline \multirow{3}{*}{$\begin{array}{c}\text { Model } \\
\text { Cassona }\end{array}$} & Lepkość Cassona $[\mathrm{Pa} \cdot \mathrm{s}]$ & 0,0635 & 0,0623 & 0,0657 & 0,0749 & 0,0586 & 0,0627 & 0,0943 & 0,1024 \\
\hline & Granica płynięcia [Pa] & 2,9038 & 4,1442 & 4,1373 & 4,7122 & 0,2450 & 0,2345 & 0,6961 & 0,7491 \\
\hline & Współczynnik korelacji [-] & 0,9993 & 0,9985 & 0,9998 & 0,9999 & 0,9998 & 0,9997 & 0,9992 & 0,9993 \\
\hline \multirow{4}{*}{$\begin{array}{c}\text { Model } \\
\text { Herschela- } \\
\text { Bulkleya }\end{array}$} & Granica płynięcia [Pa] & 4,8629 & 6,8416 & 6,1903 & 6,8915 & 0,5304 & 0,5098 & 0,9597 & 1,1267 \\
\hline & Współczynnik konsystencji $\left[\mathrm{Pa} \cdot \mathrm{s}^{\mathrm{n}}\right]$ & 0,1914 & 0,1771 & 0,2734 & 0,3322 & 0,1242 & 0,1338 & 0,2929 & 0,3062 \\
\hline & Wykładnik potęgowy [-] & 0,8916 & 0,9097 & 0,8509 & 0,8414 & 0,9064 & 0,9042 & 0,8547 & 0,8603 \\
\hline & Współczynnik korelacji [-] & 0,9999 & 1,0000 & 1,0000 & 1,0000 & 1,0000 & 1,0000 & 1,0000 & 1,0000 \\
\hline
\end{tabular}

a dolnym punktem pomiaru w zakresie od $5 \mathrm{~kg} / \mathrm{m}^{3}$ do $15 \mathrm{~kg} / \mathrm{m}^{3}$. Natomiast po zastosowaniu domieszki perlitu pylistego zaczyn charakteryzował się homogeniczną strukturą, w której gęstość posiadała stałą wartość we wszystkich punktach pomiaru (górna, środkowa oraz dolna część kolumny pomiarowej).

Wprowadzenie do receptury zaczynu domieszki perlitu pylistego skutkowało również obniżeniem wartości rozlewności opracowywanych zaczynów. Uzyskano 10-milimetrowe obniżenie wartości rozlewności we wszystkich receptu- rach zawierających perlit w porównaniu $\mathrm{z}$ odpowiadającymi im zaczynami bazowymi (bez domieszki perlitu).

Analizując wartości odstoju wody w zaczynach $\mathrm{z}$ dodatkiem perlitu, obserwuje się trend wzrostowy. Dla większości receptur z domieszką lekkich frakcji perlitu wartość odstoju wody wzrastała trzykrotnie. Jedynie w zaczynie z chlorkiem wapnia wartość odstoju powiększyła się dwukrotnie. Przyczyną powyższego efektu może być wspominana wcześniej higroskopijność $\mathrm{CaCl}_{2}$, która powoduje absorpcję pewnej 


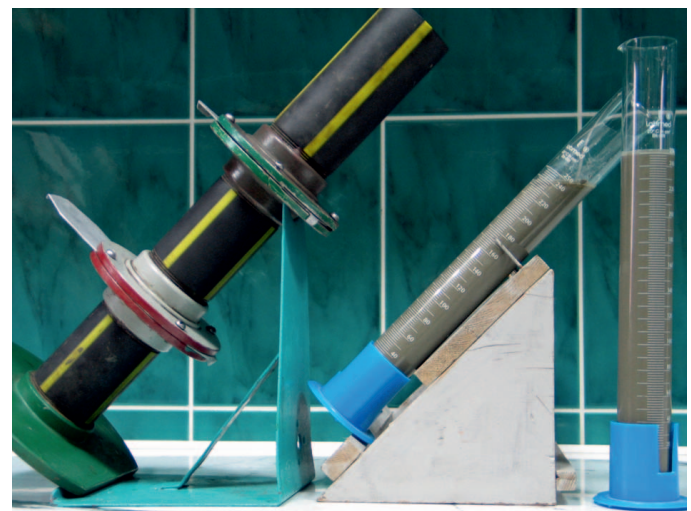

Fot. 1. Stanowisko do oznaczania stabilności sedymentacyjnej zaczynu cementowego i odstoju wody (po lewej - kolumna sedymentacyjna, po prawej - cylindry do pomiaru odstoju wody)

ilości wody, w efekcie wydzielonej w mniejszej ilości jako wspominana wartość odstoju wody. Uzyskane wyniki zestawiono w tablicy 2 oraz na rysunku 2 .

Podczas analizy wartości filtracji zaczynu zaobserwowano podobne zachowania zaczynu jak przy interpretacji wartości odstoju wody. Zaczyn $\mathrm{nr} 2$ (zawierający $\mathrm{CaCl}_{2}$ ) charakteryzował się obniżeniem filtracji do $27 \mathrm{~cm}^{3} / 30 \mathrm{~min}$ po zasto- sowaniu domieszki perlitu, w porównaniu z zaczynem bazowym, w którym uzyskano filtrację równą $46 \mathrm{~cm}^{3} / 30 \mathrm{~min}$. Również w tym przypadku można wziąć pod uwagę działanie higroskopijne chlorku wapnia, zastosowanego w celu przyspieszenia czasu wiązania i gęstnienia zaczynu. Pozostałe receptury zmodyfikowane domieszką perlitu pylistego posiadały znacznie wyższe wartości filtracji w porównaniu z odpowiadającymi im recepturami kontrolnymi (tablica 2 ).

Rozpatrując wpływ domieszki perlitu na czas gęstnienia zaczynu cementowego, zaobserwowano nieznaczne skrócenie zarówno początku czasu gęstnienia równego $30 \mathrm{Bc}^{3}$, jak i końca czasu gęstnienia opisywanego wartością 100 Bc. Efekt ten uzyskano dla wszystkich receptur, a otrzymane wyniki przedstawiono w tablicy 2 oraz na rysunku 5 .

Zestawienie wartości parametrów reologicznych przedstawiono w tablicy 3 oraz na rysunku $6 \mathrm{w}$ celu zobrazowania zmian zachodzących pod wpływem zastosowanej domieszki perlitu pylistego. Zauważalny jest trend wzrostowy

\footnotetext{
${ }^{3} \mathrm{Bc}$ - jednostka czasu gęstnienia zaczynu cementowego podczas pomiaru w konsystometrze (jednostka Beardena).
}

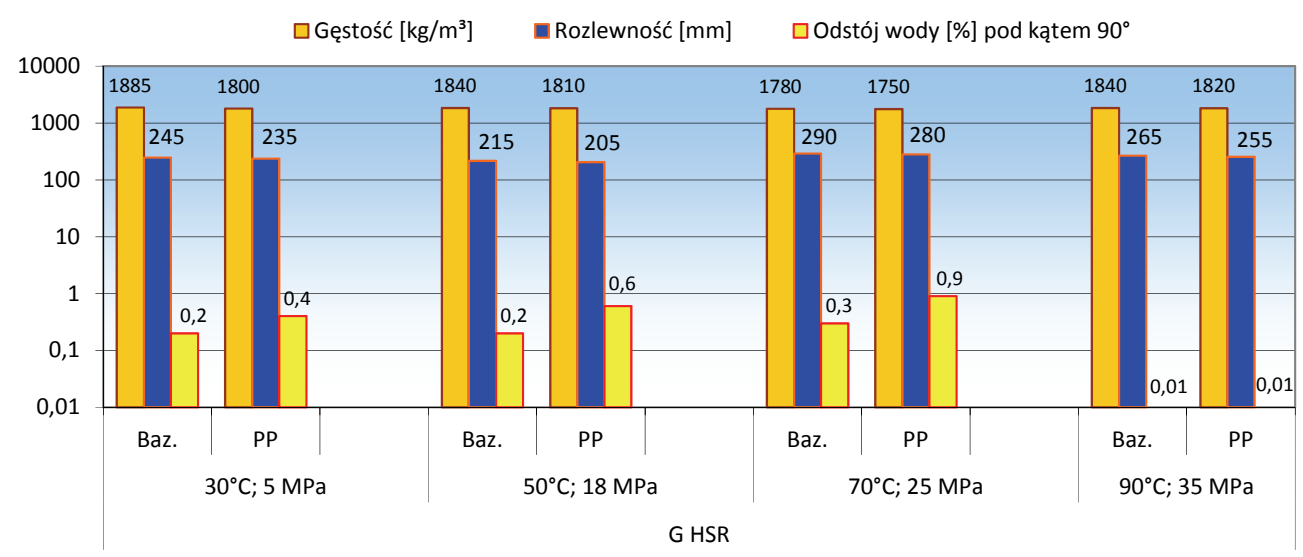

Rodzaj zaczynu; warunki hydratacji; rodzaj spoiwa

Rys. 2. Zestawienie wyników badań gęstości, rozlewności i odstoju wody świeżych zaczynów cementowych

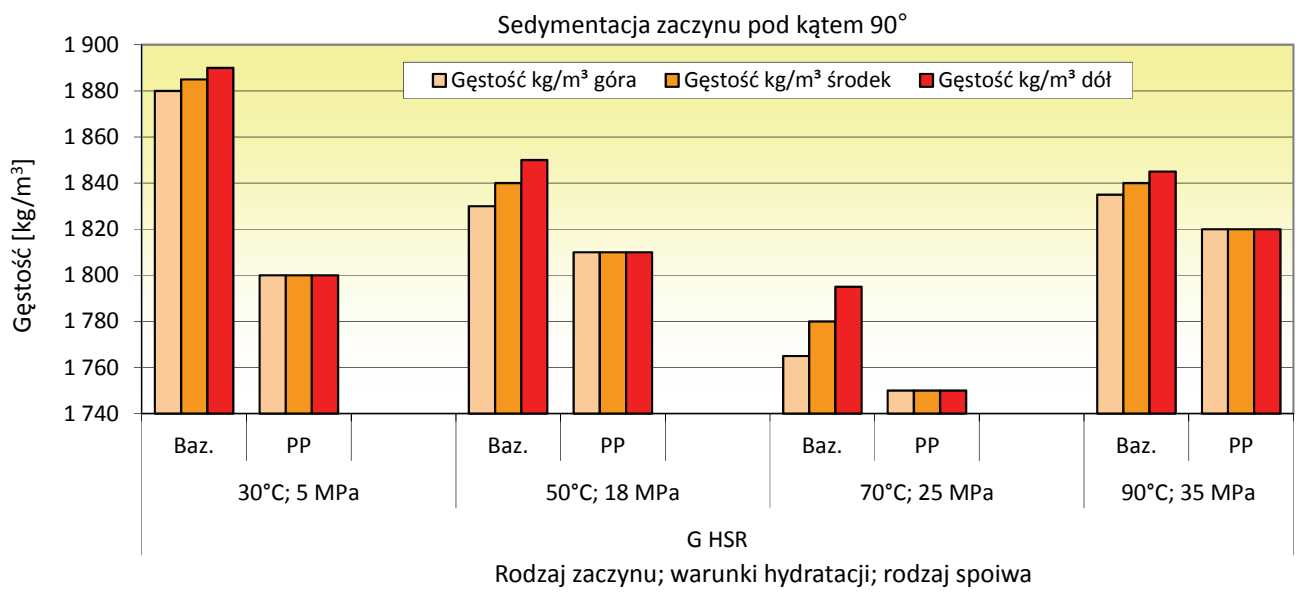

Rys. 3. Zestawienie gęstości zaczynu w poszczególnych punktach pomiarowych kolumny sedymentacyjnej 


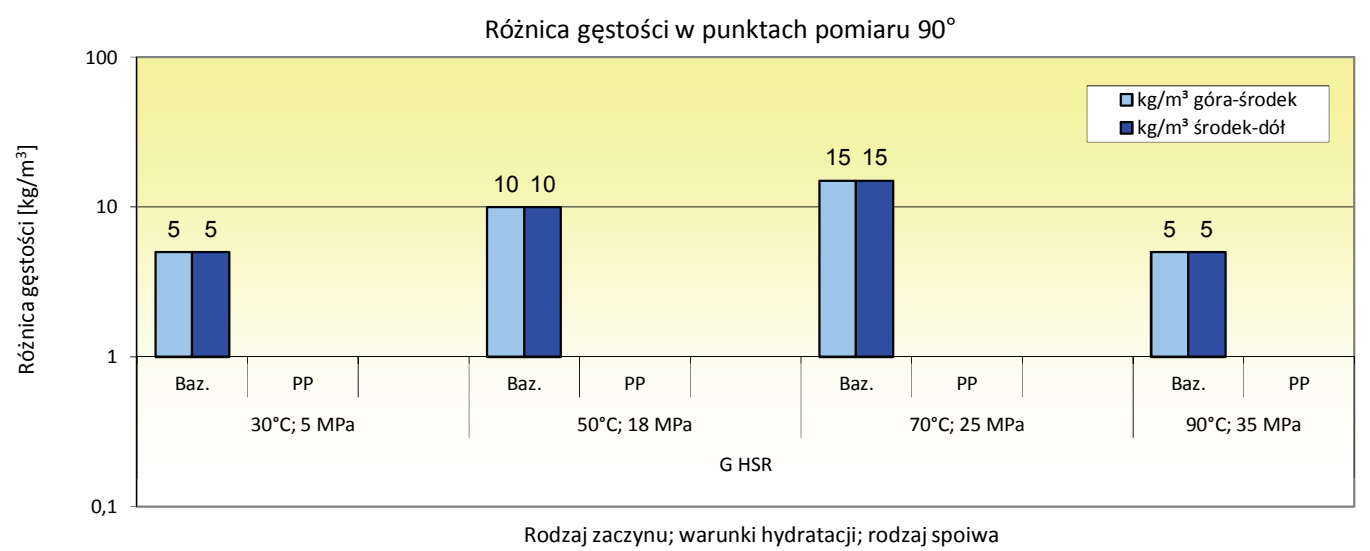

Rys. 4. Porównanie różnic gęstości w poszczególnych punktach pomiarowych kolumny sedymentacyjnej (różnica pomiędzy górną a środkową częścią oraz różnica pomiędzy środkową a dolną częścią kolumny)

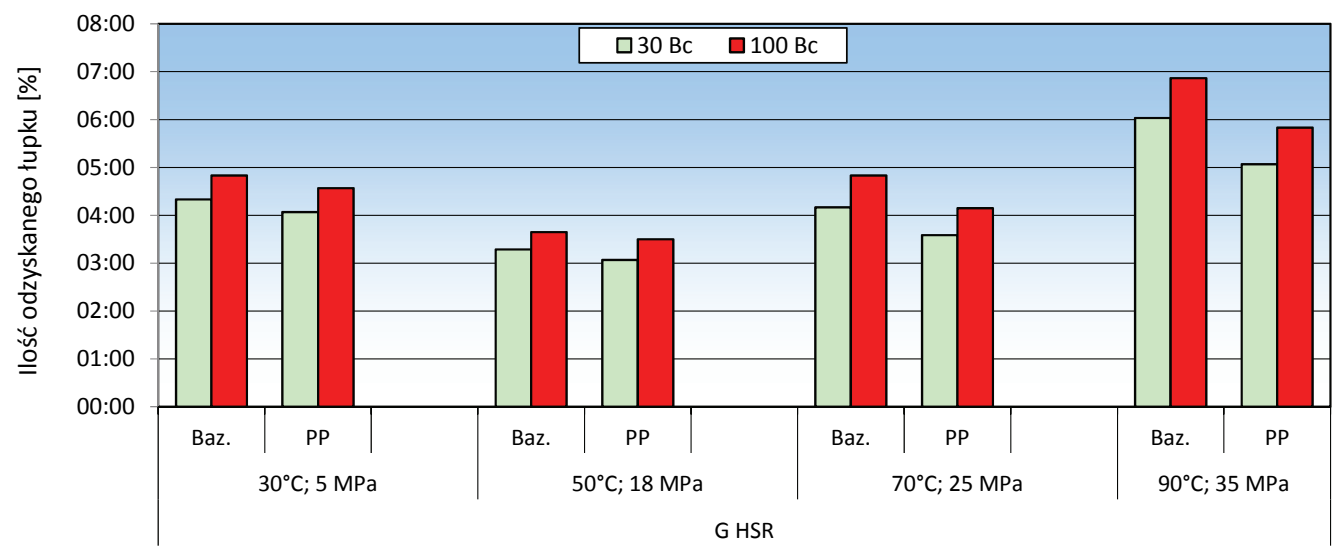

Rys. 5. Zestawienie pomiarów czasu gęstnienia zaczynów cementowych

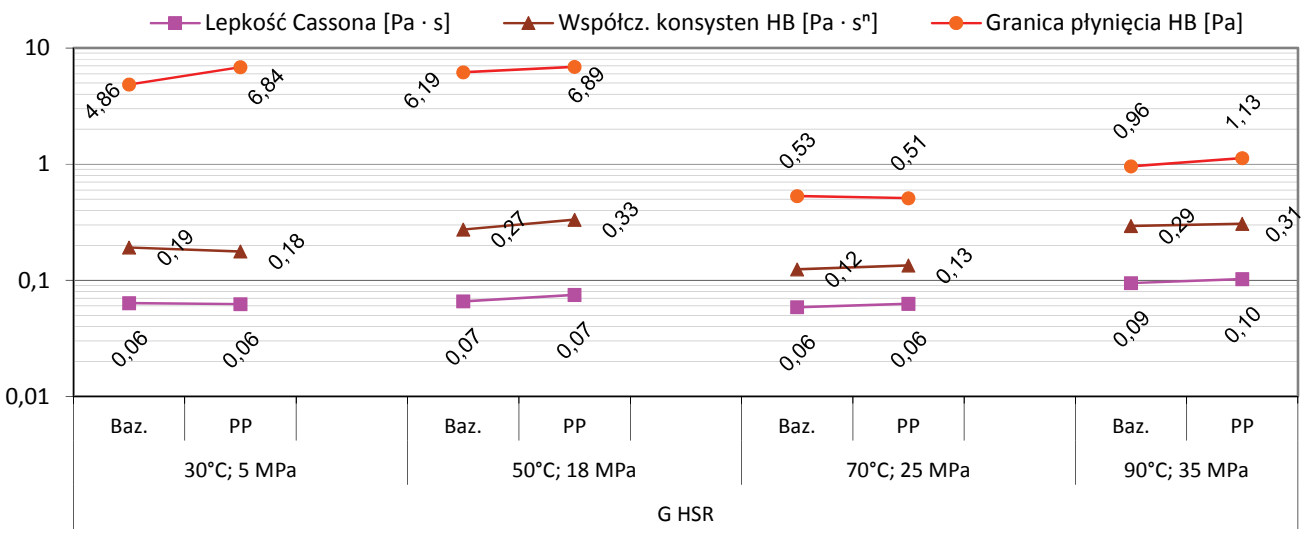

Rodzaj zaczynu; warunki hydratacji; rodzaj spoiwa

Rys. 6. Zestawienie wyników badań parametrów reologicznych zaczynów cementowych

granicy płynięcia opisywanej modelem Hershela Bulkleya. Efekt ten widoczny jest dla większości receptur, jednak zaczyn dla warunków temperatury $70^{\circ} \mathrm{C}$ i ciśnienia $25 \mathrm{MPa}$ wykazuje tendencję odwrotną (nieznaczne obniżenie wartości granicy płynięcia). Może to być spowodowane większą wartością współczynnika wodno-cementowego (większa ilość wody), który wynosił dla tej receptury 0,57 ; natomiast pozostałe składy zaczynów sporządzono przy zastosowaniu $\mathrm{w} / \mathrm{c}=0,50$. Analizując wyniki lepkości plastycznej Cassona, zaobserwowano jej nieznaczne zmiany (głównie wzrost) po zastosowaniu domieszki perlitu. Są to jednak zmiany rzędu tysięcznych części $\mathrm{Pa} \cdot \mathrm{s}$.

Podczas analizy wpływu domieszki perlitu pylistego na parametry mechaniczne stwardniałych zaczynów cementowych wykonane zostały badania wytrzymałości na ściskanie, przyczepności do rur stalowych oraz przyczepności do skały, którą reprezentowała wzorcowa próbka piaskowca. Dodatkowo przeprowadzono badania wpływu domieszki perlitu 
Tablica 4. Parametry stwardniałych zaczynów cementowych

\begin{tabular}{|c|c|c|c|c|c|c|c|c|c|c|c|c|c|}
\hline \multirow{4}{*}{$\begin{array}{c}\mathrm{Nr} \\
\text { próbki }\end{array}$} & \multirow{4}{*}{$\begin{array}{c}\text { Rodzaj } \\
\text { domieszki }\end{array}$} & \multirow{4}{*}{$\begin{array}{l}\text { Warunki } \\
\text { hydratacji } \\
\text { [temp., } \\
\text { ciśn.] }\end{array}$} & \multicolumn{11}{|c|}{ Badany parametr stwardniałego zaczynu } \\
\hline & & & \multicolumn{3}{|c|}{$\begin{array}{c}\text { wytrzymałość } \\
\text { na ściskanie } \\
{[\mathrm{MPa}]}\end{array}$} & \multicolumn{3}{|c|}{$\begin{array}{c}\text { przyczepność } \\
\text { do rur stalowych } \\
{[\mathrm{MPa}]}\end{array}$} & \multicolumn{3}{|c|}{$\begin{array}{c}\text { przyczepność } \\
\text { do skały [MPa] }\end{array}$} & \multirow[t]{2}{*}{$\begin{array}{c}\text { przepusz- } \\
\text { czalność } \\
{[\mathrm{mD}]}\end{array}$} & \multirow[t]{2}{*}{$\begin{array}{c}\text { porowa- } \\
\text { tość } \\
{[\%]}\end{array}$} \\
\hline & & & \multicolumn{9}{|c|}{ czas hydratacji } & & \\
\hline & & & 2 dni & 7 dni & $28 \mathrm{dni}$ & $2 \mathrm{dni}$ & 7 dni & $28 \mathrm{dni}$ & 2 dni & $7 \mathrm{dni}$ & $28 \mathrm{dni}$ & \multicolumn{2}{|c|}{$28 \mathrm{dni}$} \\
\hline 1. & baz. & \multirow{2}{*}{$\begin{array}{c}30^{\circ} \mathrm{C} \\
5 \mathrm{MPa}\end{array}$} & 9,3 & 11,6 & 13,0 & 6,2 & 7,5 & 8,7 & 2,16 & 2,64 & 2,95 & 0,12 & 37,15 \\
\hline 2. & PP & & 9,0 & 11,4 & 11,8 & 5,1 & 6,8 & 8,6 & 2,05 & 2,14 & 2,59 & 0,09 & 39,42 \\
\hline 3. & baz. & \multirow{2}{*}{$\begin{array}{c}50^{\circ} \mathrm{C} \\
18 \mathrm{MPa}\end{array}$} & 9,3 & 12,3 & 12,7 & 6,2 & 7,8 & 8,5 & 2,11 & 2,81 & 3,04 & 0,14 & 36,92 \\
\hline 4. & PP & & 8,6 & 11,4 & 12,1 & 4,1 & 5,8 & 7,0 & 1,85 & 1,95 & 2,29 & 0,15 & 38,88 \\
\hline 5. & baz. & \multirow{2}{*}{$\begin{array}{c}70^{\circ} \mathrm{C} \\
25 \mathrm{MPa}\end{array}$} & 9,7 & 11,0 & 12,5 & 6,2 & 7,4 & 7,9 & 2,11 & 2,51 & 2,78 & 0,18 & 37,01 \\
\hline 6. & PP & & 8,8 & 10,6 & 11,3 & 4,9 & 6,2 & 7,6 & 1,90 & 2,03 & 2,41 & 0,15 & 37,43 \\
\hline 7. & baz. & \multirow{2}{*}{$\begin{array}{c}90^{\circ} \mathrm{C} \\
35 \mathrm{MPa}\end{array}$} & 10,7 & 12,8 & 13,6 & 6,7 & 8,2 & 9,0 & 2,22 & 2,93 & 3,28 & 0,09 & 34,21 \\
\hline 8. & PP & & 8,6 & 11,0 & 11,9 & 4,0 & 5,5 & 6,8 & 1,80 & 1,06 & 2,31 & 0,07 & 35,12 \\
\hline
\end{tabular}

na przepuszczalność oraz porowatość próbki. Uzyskane wyniki badań zestawiono w tablicy 4, gdzie kolorem szarym zaznaczono próbki charakteryzujące się poprawą parametrów w porównaniu z próbkami bazowymi.

Porównując wyniki przeprowadzonych badań, zaobserwowano obniżenie wartości analizowanych parametrów: zarówno wytrzymałości na ściskanie, jak również przyczepności do rur stalowych oraz przyczepności do skały. Trend ten można w pewnym sensie tłumaczyć niewielką wytrzymałością mechaniczną stosowanej domieszki perlitu pylistego, którego obecność osłabia strukturę tworzącego się kamienia cementowego. Należy jednak zauważyć, że obniżenie omawianych wartości parametrów mechanicznych jest stosunkowo niewielkie w przypadku wprowadzenia perlitu do zaczynu nr 2, w którym zastosowano chlorek wapnia, oraz do zaczynu nr 6, który posiada wyższy niż pozostałe składy współczynnik wodno-cementowy. O ile w przypadku składu nr 6 większa ilość wody w zaczynie może mieć przełożenie na mniejsze „osłabienie” kamienia cementowego, to w przypadku zaczynu zawierającego chlorek wapnia należałoby zachodzące interakcje poddać dodatkowym szczegółowym badaniom. Zwrócić należy uwagę na fakt, że domieszka perlitu pylistego powoduje tylko nieznaczny wzrost porowatości, co jest korzystne z punktu widzenia projektowania zaczynu lekkiego wykazującego skompaktowaną mikrostrukturę. Najczęściej środki obniżające gęstość zaczynu powodują znacznie mocniejszy wzrost wartości porowatości. Ponadto zastosowanie domieszki perlitu spowodowało obniżenie przepuszczalności dla gazu. Takie funkcjonowanie domieszki drobnoziarnistych frakcji perlitu może być tłumaczone doszczelniającym działaniem zastosowanego wypełniacza.

Konkludując, należy stwierdzić, że wprowadzenie niewielkiej ilości perlitu pylistego do receptury zaczynu cementowego pozytywnie wpływa na zmianę własności technologicznych płynnego zaczynu. Objawia się to głównie poprawą stabilności sedymentacyjnej przy niemal niezmiennych parametrach reologicznych, takich jak: lepkość plastyczna, granica płynięcia i współczynnik konsystencji. Takie zachowanie zaczynów z domieszką perlitu pylistego jest bardzo pożądane, ponieważ pozwala na poprawę stabilności zaczynu przeznaczonego dla otworów kierunkowych, bez obawy o wzrost oporów tłoczenia (spowodowanych podniesieniem parametrów reologicznych) i w konsekwencji wystąpienie trudności podczas tłoczenia.

Na podstawie realizowanych badań zaobserwowano pewnego rodzaju współdziałanie domieszki perlitu i chlorku wapnia stosowanego w celu przyspieszenia czasu wiązania zaczynu. Objawia się to poprzez znacznie mocniejsze obniżenie gęstości zaczynu przy jednoczesnym zastosowaniu domieszki perlitu i $\mathrm{CaCl}_{2}$ niż podczas wykorzystania samego perlitu (co miało miejsce w przypadku pozostałych składów zaczynów). Należy pamiętać, iż jednoczesne stosowanie tych środków jest możliwe tylko w przypadku zaczynów projektowanych dla niskich temperatur i przeznaczonych do uszczelniania kolumn rur okładzinowych posadowionych na niewielkich głębokościach. Wiąże się to z faktem, że chlorek wapnia znacznie przyspiesza czas wiązania i gęstnienia zaczynu cementowego oraz powoduje wzrost jego lepkości. Stosowana podczas badań 0,5-procentowa domieszka per- 
litu pylistego nie wykazuje wpływu na czas gęstnienia, co jest również korzystne z punktu widzenia projektowania zaczynu cementowego. Dzięki powyższemu możliwe jest regulowanie parametrów takich jak stabilność sedymentacyjna i gęstość, przy zachowaniu porównywalnego czasu gęstnienia zaczynu.

Analizując wyniki badań stwardniałych zaczynów cementowych, zaobserwowano korzystny wpływ perlitu na przepuszczalność dla gazu. Uzyskano znaczną poprawę tego parametru oraz niewielki wzrost porowatości. Taki efekt jest bardzo korzystny ze względu na konieczność otrzymania nieprzepuszczalnej i skompaktowanej mikrostruktury płasz- cza cementowego. Wspomnieć należy, że podczas stosowania innego rodzaju domieszek ,lekkich”, takich jak np. mikrosfera, porowatość płaszcza cementowego ulega znacznemu wzrostowi. Domieszka perlitu pylistego powoduje niestety obniżenie parametrów mechanicznych (wytrzymałość na ściskanie, przyczepność do rur stalowych i formacji skalnej) stwardniałego zaczynu. Związane jest to z niską wytrzymałością materiału, jakim jest perlit. Powyższe testy można potraktować jako propozycję do dalszych prac badawczych, których celem będzie opracowanie receptury z domieszką perlitu wykazującej jednocześnie zadowalające wartości parametrów mechanicznych.

\section{Wnioski}

Na podstawie analizy wpływu domieszki perlitu pylistego na własności technologiczne zaczynu cementowego wyciągnięto następujące wnioski:

1. Wprowadzenie drobnych frakcji perlitu do receptury zaczynu cementowego zawierającego różne dodatki i domieszki powinno być badane w odniesieniu do konkretnego składu zaczynu.

2. Domieszka perlitu pylistego powoduje nieznaczne obniżenie gęstości zaczynu cementowego.

3. Obniżenie gęstości zaczynu cementowego poprzez zastosowanie domieszki perlitu jest wzmacniane obecnością chlorku wapnia.

4. Domieszka perlitu do zaczynu cementowego powoduje poprawę jego stabilności sedymentacyjnej przy jednocześnie niemal niezmiennej reologii płynnego zaczynu.
Składy z 0,5-procentową ilością perlitu nie ulegają frakcjonowaniu wskutek działających sił grawitacji.

5. Perlit pylisty powoduje wzrost wartości filtracji oraz odstoju wody zaczynów cementowych niezawierających w składzie chlorku wapnia.

6. Obecność perlitu pylistego w recepturze zaczynu nie wpływa znacząco na zmianę jego czasu gęstnienia podczas badania w konsystometrze HTHP.

7. Analizując parametry mechaniczne zaczynów cementowych z domieszką perlitu pylistego, zaobserwowano obniżenie wartości wytrzymałości na ściskanie, przyczepności do rur stalowych i przyczepności do skały.

8. Wprowadzenie perlitu do zaczynu skutkuje doszczelnieniem matrycy płaszcza cementowego, objawiającym się obniżeniem przepuszczalności dla gazu.

Prosimy cytować jako: Nafta-Gaz 2017, nr 12, s. 943-952, DOI: 10.18668/NG.2017.12.05

Artykuł nadesłano do Redakcji 13.07.2017 r. Zatwierdzono do druku 3.10.2017 r.

Artykuł powstał na podstawie pracy badawczej pt.: Analiza możliwości poprawy stabilności sedymentacyjnej zaczynów cementowych - praca INiG - PIB na zlecenie MNiSW; nr zlecenia: 36/KW/16, nr archiwalny: DK-4100/36/16.

\section{Literatura}

[1] Aguilera R., Cordell G., Ng M.G., Nicholl G.W., Runions G.A.: Horizontal Wells. Gulf publishing Company, Houston 1991.

[2] Armessen P., Jourdan A.P., Mariotti Ch.: Horizontal drilling gas negative and positive factors. PennWell Publishing Comp. 1988.

[3] Bandrowski J., Merta H., Zioło J.: Sedymentacja zawiesin. Zasady i projektowanie. Wydawnictwo Politechniki Śląskiej, Gliwice 1995.

[4] Barron A.R.: Hydratation of Portland Cement; http://cnx.org/ content/m16447/latest/ (dostęp: 26.01.2010).

[5] Bhatty J.I., Banfill P.F.G.: Sedimentation behaviour in cement pastes subjected to continuous shear in rotational viscometers. Cement and Concrete Research 1982.

[6] Carpenter R.B.: Matrix Control Cementing Slurry. U.S. Patent No. 4.569.395, 1986
[7] Chatterji S.: On the properties of freshly made Portland cement paste. Part 2. Sedimentation and strength of flocculation. Cement and Concrete Research 1988.

[8] Dębińska E.: Ocena działania dodatków opóźniających czas wiąania zaczynów cementowych na podstawie badań laboratoryjnych. Nafta-Gaz 2012, nr 4, s. 225-232.

[9] Dohnalik M., Zalewska J.: Korelacja wyników laboratoryjnych uzyskanych metoda rentgenowskiej mikrotomografii, jadrowego rezonansu magnetycznego i porozymetrii rtęciowej. Nafta-Gaz nr 2013, nr 10, s. 735-743.

[10] Kątna Z. i in.: Badania modelowe wplywu odstoju wody, sedymentacji i początkowego skurczu zaczynu cementowego na jakość uszczelniania rur $w$ otworach odchylonych od pionu i poziomych $w$ temperaturach do $85^{\circ} \mathrm{C}$. Praca naukowo-badawcza INiG, Kraków 1997. 
[11] Kremieniewski M., Rzepka M., Stryczek S., Wiśniowski R., Kotwica Ł., Złotkowski A.: Korelacja przepuszczalności i parametrów opisujących strukturę stwardniałych zaczynów cementowych stosowanych do uszczelniania otworów $w$ rejonie Basenu Pomorskiego. Nafta-Gaz 2015, nr 10, s. 737-746, DOI: 10.18668/NG2015.10.04.

[12] Kremieniewski M., Stryczek S., Kotwica Ł.: Zmiany w mikrostrukturze płaszcza cementowego w zależności od warunków hydratacji zaczynu. Nafta-Gaz 2014, nr 12, s. 918-926.

[13] McNaught A.D., Wilkinson A.: IUPAC. Compendium of Chemical Terminology (Gold Book). Wyd. 2. Oksford: Blackwell Scientific Publications, 1997. Wersja internetowa: Nic M., Jirat J., Kosata B.: Colloidal dispersion (ang.), aktualizowana przez Jenkins A., DOI: 10.1351/goldbook.C01174.

[14] Neville A.M.: Właściwości betonu. Kraków 2000.

[15] Perlit ekspandowany. Zastosowanie. Opracowanie Zakładów Górniczo-Metalowych „Zębiec” w Zębcu S.A., Starachowice; http://www.zebiec.pl/pliki/zastosowanie perlitu.pdf (dostęp: 06.2017).
[16] Praca zbiorowa: Rzeczpospolita tupkowa. Studium wiedzy o gazie z formacji tupkowych. Prace Naukowe INiG 2012, nr 183.

[17] Rzepka M., Stryczek S.: Laboratoryjne metody określania parametrów technologicznych świeżych zaczynów uszczelniajacych przed zabiegiem zwiazanym z procesem uszczelniania kolumn rur okładzinowych w otworach wiertniczych. Wiertnictwo, Nafta, Gaz 2008, t. 25, z. 2, s. 625-636.

[18] Sawicki J.: Perlit ekspandowany - arcymistrz termoizolacji; http://www.altex.pl/pdf/perlit.pdf chrzanów.pl (dostęp: 06.2017).

[19] Stryczek S., Gonet A., Wiśniowski R.: Wpływ wybranego dodatku mineralnego na własności technologiczne zaczynów cementowych. Wiertnictwo, Nafta, Gaz 2005, t. 22, z. 1, s. 333-341.

[20] Stryczek S., Wiśniowski R., Gonet A., Złotkowski A.: The influence of time of rheological parameters of fresh cement slurries. AGH Drilling, Oil, Gas 2014, vol. 31, s. 123-133.

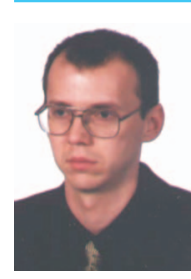

Dr inż. Marcin RZEPKA

Kierownik Laboratorium Zaczynów Uszczelniających w Zakładzie Technologii Wiercenia. Instytut Nafty i Gazu - Państwowy Instytut Badawczy ul. Lubicz 25 A

31-503 Kraków

E-mail: marcin.rzepka@inig.pl

\section{OFERTA}

\section{ZAKŁAD PRODUKCJI DOŚWIADCZALNEJ I MAŁOTONAŻOWEJ ORAZ SPRZEDAŻY}

Zakres działania:

- $\quad$ produkcja małotonażowa i sprzedaż specyfików naftowych w ilościach od 10 do $25000 \mathrm{~kg} /$ szarżę:

» olejów i środków smarowych,

» specyfików naftowych dla wojska,

» preparatów myjących,

» inhibitorów korozji i rdzewienia,

» dodatków i pakietów dodatków uszlachetniających (dobieranie do paliw indywidualnie):

- do przerobu ropy naftowej (procesowe),

- do benzyn silnikowych,

- do paliw lotniczych,

- do olejów napędowych,

- do olejów opałowych,

- do paliw alternatywnych (biopaliw),

- biocydów do paliw naftowych i biopaliw,

- opracowywanie kart charakterystyki substancji i mieszanin niebezpiecznych zgodnie z obowiązującymi przepisami prawnymi.

Kierownik: dr Winicjusz Stanik

Adres: ul. Łukasiewicza 1, 31-429 Kraków

Telefon: 1261775 25, 126177553

Faks: 126177513,126177522

E-mail: winicjusz.stanik@inig.pl

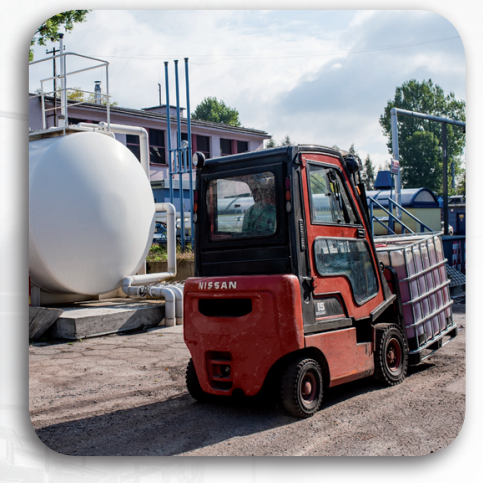

